\title{
Mycelial Growth and Enzymatic Activities of Fungi Isolated from Recycled Paper Wastes Grown on Di (2-ethylhexyl) phthalate
}

\author{
Yahayra Aguilar-Alvarado1, María del Rosario Báez-Sánchez², \\ Daniel Claudio Martínez-Carrera ${ }^{3}$, Miriam Ahuactzin-Pérez ${ }^{4}$, \\ Martín Cuamatzi-Muñoz ${ }^{5}$, Carmen Sánchez ${ }^{6 *}$
}

${ }^{1}$ Faculty of Biology, Licenciatura en Biología, UAT, Ixtacuixtla, Tlaxcala, CP, 90120, México ${ }^{2}$ Laboratory of Agrotechnology, Ingeniería en Agrotecnología, Universidad Politécnica de Tlaxcala Región Poniente,

Carr. Federal México - Veracruz Km. 85, Recova, Hueyotlipan, Tlaxcala, CP, 90240, México

${ }^{3}$ College of Postgraduates (CP), Campus Puebla, Biotechnology of Edible, Functional and Medicinal Mushrooms, Apartado Postal 129, Puebla, CP, 72001, México

${ }^{4}$ Faculty of Biology, UAT, Ixtacuixtla, Tlaxcala, CP, 90120, México

${ }^{5}$ Laboratory of Agrotechnology, Universidad Politécnica de Tlaxcala Región Poniente,

Carr. Federal México - Veracruz Km. 85, Recova, Hueyotlipan, Tlaxcala, CP, 90240, México ${ }^{6}$ Laboratory of Biotechnology, Research Centre for Biological Sciences, Universidad Autónoma de Tlaxcala, Ixtacuixtla, Tlaxcala, CP, 90120, México

Received: May 26, 2015

Accepted: July13, 2015

\begin{abstract}
Phthalate esters are often discharged into the ecosystem by paper and plastic industries during manufacturing processes, contributing to environmental pollution. Di (2-ethylhexyl) phthalate (DEHP) is a plasticizer widely used in the manufacture of plastics that imparts flexibility to polyvinyl chloride resins. This is an endocrine-disrupting compound that could lead to cancer. Filamentous fungi were isolated from mixed pulp waste in a paper recycling facility. Ribosomal DNA internal transcribed spacers sequencing were performed, which allowed for the identification of the fungal species of the isolates as Neurospora sitophila, Fusarium culmorum, Trichoderma atroviride, Hypocrea lixii, and Trichoderma harzianum. Radial growth rate $\left(\mathrm{u}_{\mathrm{r}}\right)$, mycelial biomass, and laccase and esterase activities of the fungal isolates in media containing different concentrations of DEHP $\left(0,500,750,1,000,1,200\right.$, and 1,500 mg/l) were carried out. The highest $\mathrm{u}_{\mathrm{r}}$ was shown by $N$. sitophila in the medium added with $1,500 \mathrm{mg}$ of DEHP/l. The largest mycelial biomass was produced by F. culmorum, T. atroviride, H. lixii, and T. harzianum in the medium containing 1,500 $\mathrm{mg}$ of DEHP/1. F. culmorum and T. harzianum had higher esterase activity than laccase activity in all the media tested. This study demonstrates that fungi isolated from the recycled paper wastes in a paper industry were capable of utilizing DEHP as the sole carbon source. These fungal isolates can be used for the bioremediation of DEHP-contaminated sites.
\end{abstract}

Keywords: di (2-etylhexyl) phthalate, esterase, filamentous fungi, laccase, molecular identification

*e-mail: sanher6@hotmail.com 


\section{Introduction}

Phthalate esters are often discharged by the paper and plastic industries during the manufacturing processes into the ecosystem, contributing to environmental pollution [1]. These compounds are aromatic esters widely used as plasticizers in the manufacture of plastics, which impart flexibility to polyvinyl chloride resins [2]. Phthalates are not chemically bonded to the plastics polymer and might eventually migrate from the polyvinyl chloride resins or plastics into the environment. Di (2-etylhexyl) phthalate (DEHP) is one of the most used plasticizers worldwide [3]. DEHP is an endocrine-disrupting compound that causes adverse reproductive, developmental, and immune effects in humans and wildlife, and could also lead to cancer [3, 4]. Microorganisms have been studied as an alternative pathway for phthalate biodegradation. It has been reported that esterases are enzymes involved in microbial degradation of phthalate esters [5-7]. Phthalates can be degraded by microorganisms such as Gordonia sp. [8], Pseudomona alcaligenes, P. tutzeri, Bacillus subtils, Micrococcus sp., Rhodococcus [9], Bacillus stearothermophilus [10], Fusarium sp., Trichosporon sp. [7], Pleurotus ostreatus, Irpex lacteus, Polyporus brumalis, Merulius tremellosus, Trametes versicolor, and T. versicolor TVMR12 [11, 12]. Microbial consortiums also have the capacity to degrade these compounds [2,3]. In the present research, N. sitophila, F. culmorum, T. atroviride, H. lixii, and T. harzianum were isolated from the recycling of mixed paper wastes in a paper recycling facility and were identified using an internal transcribed spacer sequence of nuclear ribosomal DNA
(ITS). Radial growth rate $\left(\mathrm{u}_{\mathrm{r}}\right)$ mycelial biomass, and laccase and esterase activities of these filamentous fungi were evaluated in media containing $0,500,750,1,000,1,200$, and $1,500 \mathrm{mg}$ of DEHP/1.

\section{Experimental Procedures}

Sampling and Growth of the Fungal Isolates

Samples were taken from three different stages (pulping, addition of biocide, and pretreatment of pulping wastewater) from a recycled paper facility that converts paper wastes into cardboard rolls. The process can be described as follows: paper wastes are placed in a pulp mixer using a forklift truck (called pulping), and then biocide is added to the pulp in order to reduce the presence of microorganisms. Soaked paper (pulping material containing biocide) is transformed into a long sheet of paper using heated metal rollers that compress and further dry the paper through evaporation. The long sheets of paper are converted into cardboard rolls using a bobbin winding machine. Water from the draining stage is stored in tanks for pretreatment of pulping wastewater and activated sludge is obtained by precipitation from the wastewater treatment plant. Treated pulping wastewater is stored in a large tank (Fig. 1). Samples were inoculated in the agar surface of plates containing malt extract agar using a sterile loop. The plates were incubated up to $7 \mathrm{~d}$ at $25^{\circ} \mathrm{C}$. Colonies were separated on the basis of morphological parameters, isolated onto individual plates, and purified by transfer where necessary.

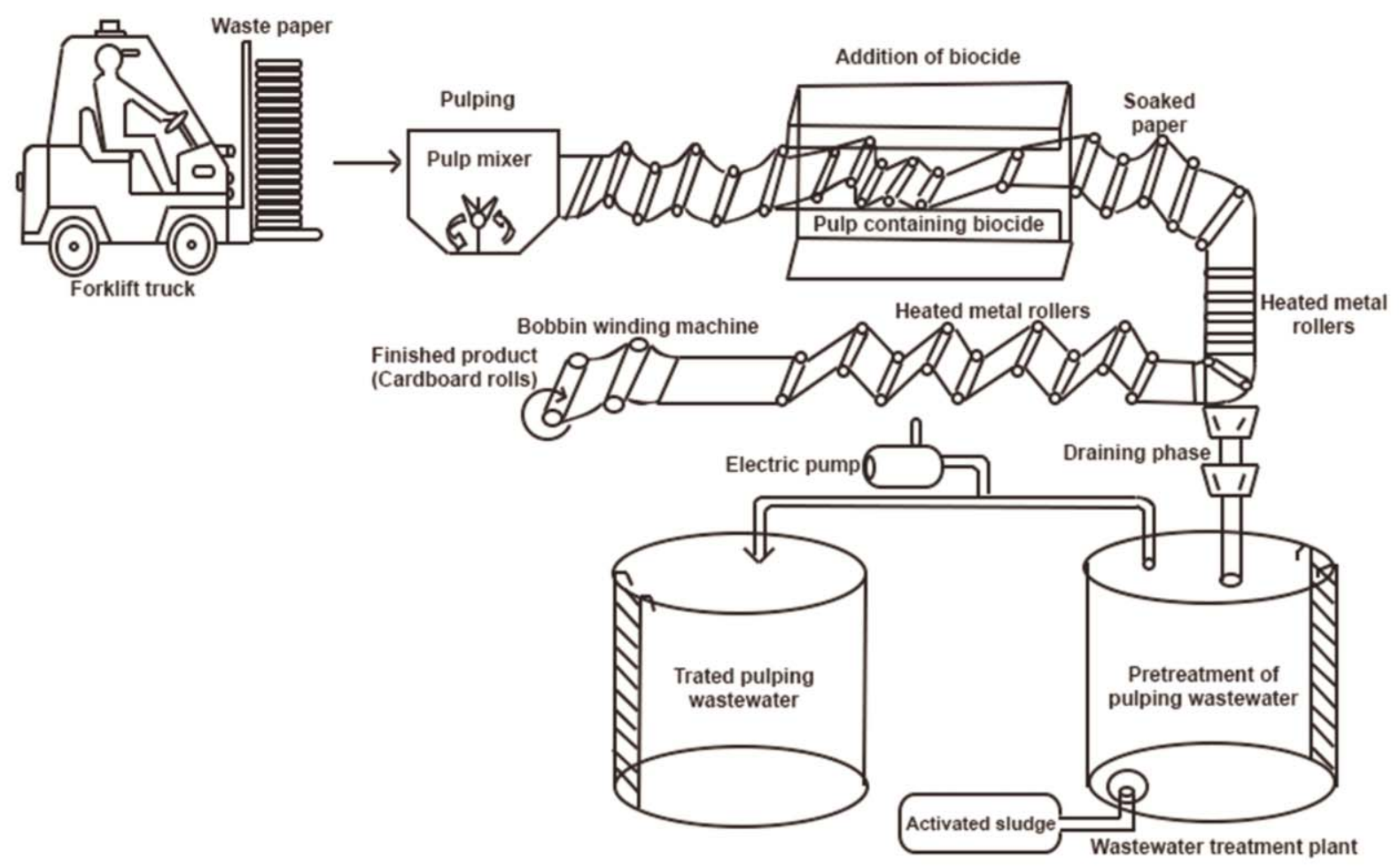

Fig. 1. Schematic representation of a paper recycling facility showing the production of cardboard rolls as final product. 
Table 1. Identification of fungal isolates from three different stages of the recycling of mixed paper wastes in a paper recycling facility.

\begin{tabular}{|l|l|c|c|}
\hline \multicolumn{1}{|c|}{ Stage of recycling } & \multicolumn{1}{|c|}{ Closest match } & $\%$ homology & GenBank accession number \\
\hline Pulping & Neurospora sitophila (Shear and B.O. Dodge) & $99 \%$ & HF947519 \\
\hline Pulping & Fusarium culmorum (W.G. Sm. Sacc.) & $91 \%$ & HF947520 \\
\hline Addition of biocide & Trichoderma atroviride (P. Karst) & $100 \%$ & HF947518 \\
\hline Preteatment of pulping wastewater & Hypocrea lixii (Pat) & $97 \%$ & HF947522 \\
\hline Preteatment of pulping wastewater & Trichoderma harzianu (Rifai) & $100 \%$ & HF947517 \\
\hline
\end{tabular}

\section{DNA Extraction and Identification of Fungi}

Individual fungal strains were grown in potato dextrose agar plates for $7 \mathrm{~d}$ at $25^{\circ} \mathrm{C}$. The mycelia were removed from the agar and the DNA extraction was carried out as previously reported [13]. To identify isolates, DNA was amplified by PCR using the primers ITS1 (TCCGTAGGTGAACCTGCGG) and ITS4 (TCCTCCGCTTATTGATATGC) [14]. The PCR conditions were as follows: initial activation of the Taq-DNA-Polymerase for $1 \mathrm{~min}$ at $95^{\circ} \mathrm{C}$, followed by 25 cycles of $30 \mathrm{~s}$ denaturation at $94^{\circ} \mathrm{C}$, annealing for $45 \mathrm{~s}$ at $50^{\circ} \mathrm{C}$, and extension for $5 \mathrm{~min}$ at $72^{\circ} \mathrm{C}$. Each PCR reaction was carried out using AmpliTaq Gold PCR kit (Applied Biosystems, E.U.A.), consisting of $25 \mu \mathrm{l}$ of master mix, $5 \mu \mathrm{l}$ of $10 \mathrm{mM}$ of each primer, $2 \mu \mathrm{l}$ DNA template (ca $50 \mathrm{ng}$ ), and $13 \mu \mathrm{l}$ of water (final volume of $50 \mu \mathrm{l}$ ). PCR products were then sequenced by Seq Wright DNA Technology Services (U.S.A.) and used to interrogate the European Bioinformatic Institute (EBI, Cambridge, England; www.ebi.ac.uk/ena).

\section{Culture Media}

Six culture media were used:

1) mineral medium (MM)

2) $\mathrm{MM}+500 \mathrm{mg}$ of $\mathrm{DEHP} / \mathrm{l}$

3) $\mathrm{MM}+750 \mathrm{mg}$ of $\mathrm{DEHP} / 1$

4) $\mathrm{MM}+1,000 \mathrm{mg}$ of DEHP/1

5) $\mathrm{MM}+1,200 \mathrm{mg}$ of $\mathrm{DEHP} / 1$

6) $\mathrm{MM}+1,500 \mathrm{mg}$ of $\mathrm{DEHP} / \mathrm{l}$.

The MM contained (in $\mathrm{g} / \mathrm{l}$ ): $\mathrm{KH}_{2} \mathrm{PO}_{4}, 0.5$; $\mathrm{MgSO}_{4} \cdot 7 \mathrm{H}_{2} \mathrm{O}, 0.5 ;\left(\mathrm{NH}_{4}\right)_{2} \mathrm{SO}_{4}, 1.0 ; \mathrm{CaH}_{4}\left(\mathrm{PO}_{4}\right) \cdot \mathrm{H}_{2} \mathrm{O}, 0.3$; $\mathrm{FeSO}_{4} \cdot 7 \mathrm{H}_{2} \mathrm{O}, 0.2 ; \mathrm{ZnSO}_{4} \cdot 7 \mathrm{H}_{2} \mathrm{O}, 0.2$; and $\mathrm{MnSO}_{4} \cdot 7 \mathrm{H}_{2} \mathrm{O}$, 0.2 . The $\mathrm{pH}$ was adjusted to 6.0 using $1 \mathrm{M} \mathrm{NaOH}$. DEHP was added to the sterile $\mathrm{MM}$ and then the culture media were sonicated in aseptic conditions for approximately three minutes using an ultrasonic processor (GEX 130) until the DEHP was fully dispersed. Petri plates were made with MM supplemented with different concentrations of DEHP as mentioned above.

\section{Radial Growth Rate and Mycelial Biomass}

Petri dishes were inoculated in the center of the plate using inoculum ( $4 \mathrm{~cm}$ of diam) from the periphery of each fungal strain grown on potato dextrose agar. The radius of the mycelial growth was measured every $4 \mathrm{~h}$ in $N$. sitophyla colonies; every $8 \mathrm{~h}$ in T. harzianum, T. atroviride, and H. lixii colonies; and every $12 \mathrm{~h}$ in F. culmorum colonies using a digital Vernier (Mitutoyo) until full invasion of the plates. The radial growth rate $\left(\mathrm{u}_{\mathrm{r}}\right)$ was calculated as the slope of the radius of mycelial growth (measured as mentioned above) versus time plots (times specified above), analyzed by linear regression [15]. The mycelial biomass was evaluated in each plate after full invasion of the culture media. The mycelia were separated from the culture media using a boiling-water bath in a pre-weighed watch glass. This was weighed, and then oven-dried at $60^{\circ} \mathrm{C}$ for $24 \mathrm{~h}$, then weighed again [15].

\section{Extracellular Laccase and Esterase Activities}

Mycelia were removed and discarded using a scalpel from the surface of well-developed colonies of the fungal isolates grown on Petri dishes containing the media tested. The extracellular enzymatic extract (EE) was obtained from the surfaces of these Petri dishes that were flooded with sterile deionized water $(25 \mathrm{ml})$ for $24 \mathrm{~h}$ using a glass Pasteur pipette. Laccase activity was determined in the EE by changes in the absorbance at $468 \mathrm{~nm}$ (using a Jenway 6405UV/Vis spectrophotometer), using 2, 6-dimethoxyphenol (DMP, SIGMA) as substrate. The assay mixture contained $900 \mu \mathrm{L}$ of $2 \mathrm{mM}$ DMP in $0.1 \mathrm{M}$ acetate buffer $\mathrm{pH} 4.5$ and $100 \mu \mathrm{l}$ of either enzymatic extract, which were incubated at $40^{\circ} \mathrm{C}$ for $1 \mathrm{~min}$. Esterases activity was determined by changes in the absorbance at $405 \mathrm{~nm}$ (using a Jenway 6405UV/Vis spectrophotometer), using p-nitrophenyl butyrate $(p N P B)$ as substrate. The reaction mixture contained $10 \mu \mathrm{l}$ of $p$ NPB solution $(1.76 \%(\mathrm{v} / \mathrm{v})$ of $p \mathrm{NPB}$ in acetonitrile), $790 \mu \mathrm{l}$ of $50 \mathrm{mM}$ phosphate buffer $\mathrm{pH} 7.0,0.04 \%$ Triton $\mathrm{X}-100$, and $100 \mu \mathrm{l}$ of EE, which were incubated at $37^{\circ} \mathrm{C}$ for $5 \min [16,17]$. One enzymatic unit of laccase activity or esterase activity $(\mathrm{U})$ is defined as the amount of enzyme that gives an increase of 1 unit of absorbance per min in the reaction mixture. The enzymatic activities were expressed in U/1 of enzymatic extract.

\section{Statistical Analysis}

All the experiments were carried out in triplicate. Data were evaluated using one-way ANOVA and Tukey post-test using the Graph Pad Prism program. 
Table 2. Radial growth rate $(\mathrm{mm} / \mathrm{h})$ of filamentous fungi isolated from the recycling of mixed paper grown on different concentrations of DEHP.

\begin{tabular}{|c|c|c|c|c|c|c|}
\hline \multirow{3}{*}{ Strain } & \multicolumn{6}{|c|}{ Concentration of DEHP (mg/l) } \\
\hline & 0 & 500 & 750 & 1,000 & 1,200 & 1,500 \\
\hline & \multicolumn{6}{|c|}{$10^{-3}$} \\
\hline Neurospora sitophila & $460^{\mathrm{c}}(0.1)$ & $340^{\mathrm{d}}(0.05)$ & $480^{c}(0.006)$ & $1,005^{\mathrm{b}}(0.02)$ & $1,006^{\mathrm{b}}(0.5)$ & $1190^{\mathrm{a}}(0.03)$ \\
\hline Fusarium culmorum & $300^{\mathrm{d}}(0.01)$ & $300^{\mathrm{d}}(0.007)$ & $310^{\mathrm{d}}(0.005)$ & $550^{\mathrm{c}}(0.009)$ & $890^{\mathrm{a}}(0.02)$ & $750^{\mathrm{b}}(0.005)$ \\
\hline Trichoderma atroviride & $500^{c}(0.04)$ & $640^{\mathrm{b}}(0.02)$ & $560^{\mathrm{b}}(0.01)$ & $690^{\mathrm{a}}(0.004)$ & $560^{\mathrm{b}}(0.009)$ & $520^{\mathrm{d}}(0.006)$ \\
\hline Hipocrea lixii & $600^{c}(0.006)$ & $660^{\mathrm{b}}(0.001)$ & $510^{\mathrm{d}}(0.01)$ & $780^{\mathrm{a}}(0.02)$ & $490^{\mathrm{e}}(0.01)$ & $460^{f}(0.02)$ \\
\hline Trichoderma harzianum & $440^{\mathrm{d}}(0.07)$ & $530^{c}(0.004)$ & $490^{\mathrm{d}}(0.05)$ & $970^{\mathrm{a}}(0.002)$ & $740^{\mathrm{b}}(0.02)$ & $540^{\mathrm{c}}(0.06)$ \\
\hline
\end{tabular}

Means with the same letter (a, b, c, or d) within a row are not significantly different.

Numbers in parentheses correspond to standard deviation of three separate experiments.

Table 3. Mycelial biomass $\left(\mathrm{g} / \mathrm{cm}^{2}\right)$ of filamentous fungi isolated from the recycling of mixed paper grown on different concentrations of DEHP.

\begin{tabular}{|c|c|c|c|c|c|c|}
\hline \multirow{3}{*}{ Strain } & \multicolumn{6}{|c|}{ Concentration of DEHP (mg/l) } \\
\hline & 0 & 500 & 750 & 1,000 & 1,200 & 1,500 \\
\hline & \multicolumn{6}{|c|}{$10^{-3}$} \\
\hline Neurospora sitophila & $40^{\mathrm{d}}(0.0006)$ & $40^{\mathrm{d}}(0.001)$ & $50^{\mathrm{d}}(0.001)$ & $65^{\mathrm{c}}(0.001)$ & $120^{\mathrm{a}}(0)$ & $80^{\mathrm{b}}(0.001)$ \\
\hline Fusarium culmorum & $45^{\mathrm{e}}(0.001)$ & $50^{\mathrm{e}}(0.001)$ & $70^{\mathrm{d}}(0.001)$ & $110^{c}(0.002)$ & $180^{\mathrm{b}}(0.003)$ & $250^{\mathrm{a}}(0.004)$ \\
\hline Trichoderma atroviride & $20^{\mathrm{e}}(0.0006)$ & $40^{\mathrm{d}}(0.0006)$ & $50^{\mathrm{c}}(0.001)$ & $75^{\mathrm{b}}(0.002)$ & $75^{\mathrm{b}}(0.001)$ & $105^{\mathrm{a}}(0.004)$ \\
\hline Hipocrea lixii & $30^{c}(0.0006)$ & $30^{c}(0.001)$ & $66^{\mathrm{b}}(0.001)$ & $66^{\mathrm{b}}(0.006)$ & $89^{\mathrm{a}}(0.001)$ & $89^{\mathrm{a}}(0.003)$ \\
\hline Trichoderma harzianum & $45^{\mathrm{d}}(0.0004)$ & $60^{c}(0.001)$ & $80^{\mathrm{b}}(0.006)$ & $80^{\mathrm{b}}(0.003)$ & $80^{\mathrm{b}}(0.002)$ & $100^{\mathrm{a}}(0.004)$ \\
\hline
\end{tabular}

Means with the same letter (a, b, c, d, or e) within a row are not significantly different.

Numbers in parentheses correspond to standard deviation of three separate experiments.

\section{Results}

\section{Fungal Isolates}

N. sitophila and F. culmorum were isolated from the pulping, T. atroviride was isolated from the pulp containing biocide, and $H$. lixii and T. harzianum were isolated from the pretreatment of pulping wastewater of the recycling of mixed paper wastes in a recycled paper industry (Table 1).

\section{Radial Growth Rate}

T. atroviride, $H$. lixii, and T. harzianum showed the largest $u_{\mathrm{r}}$ in media containing 1,000 mg of DEHP/l. F. culmorum had the greatest $\mathrm{u}_{\mathrm{r}}$ in medium added with $1,200 \mathrm{mg}$ of DEHP/l. The highest $\mathrm{u}_{\mathrm{r}}$ was shown by $N$. sitophila in the medium added with $1,500 \mathrm{mg}$ of DEHP/1. F. culmorum, T. atroviride, and T. harzianum showed the lowest $\mathrm{u}_{\mathrm{r}}$ in the medium lacking DEHP (Table 2).

\section{Mycelial Biomass}

The largest mycelial biomass was produced by $F$. culmorum, T. atroviride, H. lixii, and T. harzianum in the medi- um containing $1,500 \mathrm{mg}$ of DEHP/1. N. sitophila had the greatest mycelial biomass in the medium added with $1,200 \mathrm{mg}$ of DEHP/l. The lowest mycelial biomass was observed in the medium lacking DEHP (Table 3).

\section{Extracellular Laccase and Esterase Assays}

$N$. sitophila had the highest extracellular laccase activity in medium added with $500 \mathrm{mg}$ of DEHP/l, followed by Thrichoderma species and $H$. lixxi in media containing 1,500 and 1,200 mg of DEHP/l, respectively (Table 4). T. harzianum showed the major extracellular esterase activity in medium containing $500 \mathrm{mg}$ of DEHP/l (Table 5). F. culmorun and T. harzianum had higher esterase activity than laccase activity in all the media tested (Table 5). The extracellular laccase and esterase activities were lower in the medium lacking DEHP than in the medium added with $1,500 \mathrm{mg}$ of DEHP/l for all fungal isolates (Tables 4 and 5).

\section{Discussion}

In this work, two strains of Trichoderma were isolated from the recycling of mixed paper wastes in a paper recycling facility. Khokhar et al. [18] isolated Arpergillus sp. 
Table 4. Extracellular laccase activity (U/1) of filamentous fungi isolated from the recycling of mixed paper grown on different concentrations of DEHP.

\begin{tabular}{|l|c|c|c|c|c|c|}
\hline \multirow{2}{*}{\multicolumn{1}{c}{ Strain }} & \multicolumn{7}{|c|}{ Concentration of DEHP $(\mathrm{mg} / \mathrm{l})$} \\
\cline { 2 - 7 } & 0 & 500 & 750 & 1,000 & 1,200 & 1,500 \\
\hline Neurospora sitophila & $8.3^{\mathrm{e}}(0.03)$ & $33.9^{\mathrm{a}}(0.16)$ & $12.3^{\mathrm{d}}(0.009)$ & $9.3^{\mathrm{e}}(0.05)$ & $18.6^{\mathrm{c}}(0.06)$ & $23.1^{\mathrm{b}}(0.03)$ \\
\hline Fusarium culmorum & $7.8^{\mathrm{c}}(0.001)$ & $11.6^{\mathrm{d}}(0.03)$ & $12.4^{\mathrm{c}}(0.03)$ & $15.3^{\mathrm{b}}(0.02)$ & $8.8^{\mathrm{e}}(0.01)$ & $17^{\mathrm{a}}(0.02)$ \\
\hline Trichoderma atroviride & $4.4^{\mathrm{d}}(0.05)$ & $24.4^{\mathrm{b}}(0.05)$ & $5.5^{\mathrm{c}}(0.01)$ & $5.1^{\mathrm{c}}(0.01)$ & $5.1^{\mathrm{c}}(0.01)$ & $27.1^{\mathrm{a}}(0.001)$ \\
\hline Hipocrea lixii & $7.1^{\mathrm{d}}(0.02)$ & $11.1^{\mathrm{c}}(0.02)$ & $5^{\mathrm{e}}(0.01)$ & $7.2^{\mathrm{d}}(0.01)$ & $21.4^{\mathrm{a}}(0.05)$ & $16.1^{\mathrm{b}}(0.03)$ \\
\hline Trichoderma harzianum & $8.7^{\mathrm{c}}(0.02)$ & $8.04^{\mathrm{c}}(0.03)$ & $2^{\mathrm{e}}(0.01)$ & $7.1^{\mathrm{d}}(0.04)$ & $18.1^{\mathrm{b}}(0.06)$ & $22.3^{\mathrm{a}}(0.01)$ \\
\hline
\end{tabular}

Means with the same letter ( $a, b, c, d$, or e) within a row are not significantly different.

Numbers in parentheses correspond to standard deviation of three separate experiments.

Table 5. Extracellular esterase activity (U/1) of filamentous fungi isolated from the recycling of mixed paper grown on different concentrations of DEHP.

\begin{tabular}{|l|c|c|c|c|c|c|}
\hline \multirow{2}{*}{\multicolumn{1}{c|}{ Strain }} & \multicolumn{7}{c|}{ Concentration of DEHP $(\mathrm{mg} / \mathrm{l})$} \\
\cline { 2 - 8 } & 0 & 500 & 750 & 1,000 & 1,200 & 1,500 \\
\hline Neurospora sitophila & $11.3^{\mathrm{d}}(0.05)$ & $22.7^{\mathrm{c}}(0.05)$ & $6.5^{\mathrm{e}}(0.01)$ & $22.1^{\mathrm{c}}(0.07)$ & $38.3^{\mathrm{a}}(0.16)$ & $34.1^{\mathrm{b}}(0.12)$ \\
\hline Fusarium culmorum & $14.8^{\mathrm{e}}(0.03)$ & $69.4^{\mathrm{b}}(0.08)$ & $63.3^{\mathrm{c}}(0.16)$ & $40.3^{\mathrm{b}}(0.009)$ & $20.5^{\mathrm{d}}(0.02)$ & $55.3^{\mathrm{a}}(0.04)$ \\
\hline Trichoderma atroviride & $5.7^{\mathrm{c}}(0.04)$ & $3.6^{\mathrm{d}}(0.02)$ & $19.5^{\mathrm{b}}(0.12)$ & $3.11^{\mathrm{d}}(0.009)$ & $21^{\mathrm{b}}(0.12)$ & $27.1^{\mathrm{a}}(0.18)$ \\
\hline Hipocrea lixii & $7.1^{\mathrm{d}}(0.02)$ & $12^{\mathrm{c}}(0.01)$ & $22.3^{\mathrm{a}}(0.13)$ & $7.4^{\mathrm{d}}(0.003)$ & $18.4^{\mathrm{b}}(0.02)$ & $18^{\mathrm{b}}(0.006)$ \\
\hline Trichoderma harzianum & $39.7^{\mathrm{f}}(0.11)$ & $225.7^{\mathrm{a}}(0.14)$ & $79.4^{\mathrm{e}}(0.09)$ & $95.5^{\mathrm{d}}(0.15)$ & $122.1^{\mathrm{b}}(0.31)$ & $111.2^{\mathrm{c}}(0.30)$ \\
\hline
\end{tabular}

Means with the same letter (a, d, c, d, e, or f) within a row are not significantly different.

Numbers in parentheses correspond to standard deviation of three separate experiments.

Penicillum sp. and Trichoderma sp. from soil, from the wastewater of a paper recycling facility, and from a textile facility, respectively. T. harzianum, $T$. virile, and $A$. nidulans showed the highest cellulolytic enzymatic activity. Raju et al. [19] also isolated Trichoderma sp. from contaminated soil samples of south Indian paper mills. In the present study, fungal strains capable of degrading DEHP were isolated from the recycling of mixed paper wastes in a recycled paper industry, which could be due to the presence of phthalates in such paper wastes. It has been reported that phthalate esters are often discharged by the paper and plastic industries during the manufacturing processes into the ecosystem [1]. It has been reported that Pleurotus pulmonarius and $F$. oxysporum had higher $\mathrm{u}_{\mathrm{r}}$ in medium containing 1,000 $\mathrm{mg}$ of DEHP/1 than in medium added with glucose [20]. Suárez-Segundo et al. [20] studied the $\mathrm{u}_{\mathrm{r}}$ of Pleurotus sp., Mortierella alpine, and F. oxysporum in media containing 500 and 1,000 mg of either DEHP or dibutyl phthalate (DBP) per liter and in medium added with glucose, and reported that $F$. oxysporum had the highest $\mathrm{u}_{\mathrm{r}}$ in media containing DEHP. F. oxysporum also showed the largest mycelial biomass on media added with DEHP. In this research, the growth of the fungal isolates in the medium lacking DEHP could be due to the use by the fungi of a certain amount of nutrients that unavoidably remain in the inoculum and/or the use of nutrients produced by hyphal lysis from the inoculum as it was previously reported [20]. Kim et al. [5] reported that cutinases are enzymes able to degrade phthalates. The capability of degrading phthalates by $F$. oxysporum is due to its extracellular cutinase production $[21,22]$. Fungi have a unique enzymatic system that makes these organisms useful in bioremediation processes [23]. Hwang et al. [12] studied the degradation of butyl benzyl phthalate (BBP) $(100 \mathrm{mg} / \mathrm{l})$ by $P$. ostreatus. It was found that the degradation of this compound was higher when BBP was added to an optimum liquid medium (yeast-malt extract-glucose) than when it was added to a minimal medium, and that esterases were more important than laccases in the degradation of this phthalate. Córdoba-Sosa et al. [24] reported that the esterase activity of Pleurotus ostreatus was much higher than the laccase activity at the beginning of the stationary phase in medium containing 1,500 mg of DEHP/l in submerged fermentation.

\section{Conclusions}

In the present work, F. culmorum and T. harzianum showed higher esterase activity than laccase activity in all the media tested. This study demonstrates that fungi isolated from recycled paper waste were capable of utilizing DEHP as the sole carbon source. 


\section{References}

1. WORMUTH M., SCHERINGER M., VOLLENWEIDER M., HUNGERBUHLER K. What are the sources of exposure to eight frequently used phthalic acid esters in Europeans. Risk Anal. 26, 803, 2006.

2. LIANG D.W., ZHANG T., FANG H.H.P., HE J. Phthalates biodegradation in the environment. Appl. Microbiol. Biot. 80, 183, 2008.

3. VATS S., SINGH R.K., TYAGI P. Phthalates-a priority pollutant. Int. J. Adv. Biol. Res. 3, 1, 2013.

4. MATSUMOTO M., HIRATA-KOIZUMI M., EMA M., Potential adverse effects of phthalic acid esters on human health: a review of recent studies on reproduction. Regul. Toxicol. Pharm. 50, 37, 2008.

5. KIM Y.H., SEO H.S., MIN J., KIM Y.C., BAN Y.H., HAN K.Y., PARK K.D., BEA M.B., LEE J. Enhanced degradation and toxicity reduction of dihexyl phthalate by Fusarium oxysporum f. sp. pisi cutinase. J. Appl. Microbiol. 102, 221, 2007.

6. CHAI W., SUZUKI M, HANDA Y., MURAKAMI M., UTSUKIHARA T., HONMA Y., NAKAJIMA K., SAITO M., AKIRA A.H. Biodegradation of Di-(2-ethylhexyl) phthalate by fungi. Rep. Nat'l. Food. Res. Inst. 72, 83, 2008.

7. ZHU-HUA L., KA-LAI P., YI-RIU W., JI-DONG G., CHOW R., VRIJMOED L.P. Degradation of phthalate esters by Fusarium sp. DMT-5-3 and Trichosporon sp. DMI5-1 isolated from mangrove sediments. Prog. Mol. Subcell. Biol. 53, 299, 2012.

8. JIN D.C., BAI Z.H., CHANG D.D., HOEFEL D., JIN B., WANG P., WEI D.B., ZHUANG G.Q. Biodegradation of din-butyl phthalate by an isolated Gordonia sp. strain QH-11: Genetic identification and degradation kinetics. J. Hazard. Mater. 221, 80, 2012.

9. BENAVIDES J., QUINTERO G., GUEVARA A.L., JAIMES D.C., GUTIÉRREZ S.M., MIRANDA J. Bioremediation of crude oil contaminated soil. Publ. Cient. 4, 82, 2006.

10. UDEANI T.K.C., OBROCH A.A., OKWUOSA C.N., ACHUKWU P.U., AZUBIKE N. Isolation of bacterial from mechanic workshop soil environment contaminated with used engine oil. Afr. J. Biotechnol. 8, 6301, 2009.

11. HWANG S.S., CHOI H.T., SONG H.G. Biodegradation of endocrine-disrupting phthalate by Pleurotus ostreatus. J. Microbiol. Biotechn. 18, 767, 2008.

12. HWANG S.S., KIM H.Y., KA J.O., SONG H.G., SONG O.K. Changes in the activities of enzymes involved in the degradation of butyl benzyl phthalate by Pleurotus ostreatus. J. Microbiol. Biotechn. 22, 239, 2012.
13. CHALLEN M.P., MOORE A.J., MARTINEZ-CARRERA D. Facile extraction and purification of filamentous fungal genomic DNA. BioTechniques. 18, 975, 1995.

14. WHITE T.J., BRUNS T., LEE S., TAYLOR J. Amplification and direct sequencing of fungal ribosomal RNA genes for phylogenetics. In: PCR Protocols: a guide to methods and applications, $2^{\text {nd }}$ ed., Academic Press: New York, pp. 315$322,1990$.

15. AHUACTZIN-PÉREZ M., TORRES J.L., RODRÍGUEZ PASTRANA B.R., SORIANO SANTOS J., DÍAZ GODÍNEZ G., DÍAZ R., SÁNCHEZ C. Fungal biodegradation of dibutyl phthalate and toxicity of its breakdown products on the basis of fungal and bacterial growth. World J. Microb. Biot. 30, 2811, 2014.

16. ALVES-MACEDO G., FONTES-PIO T. A rapid screening method for cutinase producing microorganisms. Braz. J. Microbiol. 36, 388, 2005.

17. KASTHURI J., KATHIRAVAN K., RAJENDIRAN N. Phyllanthin assisted biosynthesis of silver and gold nanoparticles: a novel biological approach. J. Nanopart. Res. 11, 1075, 2009.

18. KHOKHAR I., HAIDER M.S., MUSHTAQ S., MUKHTAR I. Isolation and screening of highly cellulolytic filamentous fungi. J. Appl. Sci. Environ. Manag. 16, 223, 2012.

19. RAJU N.S., VENKATARAMANA G.V., GIRISH S.T., RAGHAVENDRA V.B., SHIVASHANKAR P. Isolation and evaluation of indigenous soil fungi for decolourization of textile dyes. J. Appl. Sci. 7, 298, 2007.

20. SUÁREZ-SEGUNDO J.L., VÁZQUEZ-LÓPEZ D., TORRES-GARCÍA J.L., AHUACTZIN-PÉREZ M., MONTIEL-MARTÍNEZ N., TLECUITL-BERISTAIN S., SÁNCHEZ C. Growth of colonies and hyphal ultrastructure of filamentous fungi grown on dibutyl phthalate and di (2etilhexil) phthalate. Rev. Mex. Ing. Quím. 12, 499, 2013.

21. CARTWRIGHT C.D., OWEN S.A., THOMPSON I.P., RICHARD G. Biodegradation of diethyl phthalate in soil by a novel pathway. FEMS. Microbiol. Lett. 186, 27, 2000.

22. CHATTERJEE S., KARLOVSKY P. Removal of the endrocrine disrupter butyl benzyl phthalate from the environment. App. Microbiol. Biotechnol. 81, 61, 2010.

23. SÁNCHEZ C. Lignocellulosic residues: Biodegradation and bioconversion by fungi. Biotechnol. Adv. 27, 185, 2009.

24. CÓRDOBA-SOSA G., TORRES J.L., AHUACTZINPÉREZ M., DÍAZ-GODÍNEZ G., DÍAZ R., SÁNCHEZ C. Growth of Pleurotus ostreatus ATCC 3526 in different concentrations of di (2-ethylhexyl) phthalate in submerged fermentation. Journal of Chemical, Biological and Physical Sciences. 4, 96, 2014. 